\title{
DOUBLE BILATERAL RENAL ARTERY IN HUMAN FETUS
}

\section{José Aderval Aragão *1, Eder Santos Souza ${ }^{2}$, Felipe Matheus Sant'Anna Aragão ${ }^{3}$, lapunira Catarina Sant'Anna Aragão ${ }^{3}$, Francisco Prado Reis ${ }^{4}$}

${ }^{{ }^{*}}$ Associate Professor, Department of Morphology and the Postgraduate Applied Health Science Programs, Federal University of Sergipe (UFS), and Titular Professor of the Medical School, Tiradentes University (UNIT), Aracaju, Sergipe, Brazil.

${ }^{2}$ Medical student at the Federal University of Sergipe (UFS), Aracaju, Sergipe, Brazil.

${ }^{3}$ Medical Student, University Center of Volta Redonda (UNIFOA), Volta Redonda, Rio de Janeiro, Brazil.

${ }^{4}$ Titular Professor, Medical School of Tiradentes University (UNIT), Aracaju, Sergipe, Brazil.

\section{ABSTRACT}

Context: The knowledge about the presence of accessory renal arteries is of great importance to surgeons, especially those who perform kidney transplants.

Objective: To report the finding of double bilateral renal artery case in human fetus.

Case Report: Duplicity of the renal artery was found in a male fetus. The right kidney received two renal arteries, one superior, measuring $6,68 \mathrm{~mm}$, and other inferior with $5,85 \mathrm{~mm}$, both steered parallel and bifurcated before penetrating the renal hilum. Likewise, the left kidney received two renal arteries, one superior, measuring 4,16 $\mathrm{mm}$ and other left with $9,93 \mathrm{~mm}$, the superior being the only one that bifurcarted itself before penetrating the renal hilum.

Conclusion: The current finding of accessory renal arteries represents collaboration not just for anatomists, but also with considerable significance to urological surgeons.

KEY WORDS: Accessory Renal Arteries, Kidney, Kidney Transplants. Renal Hilum.

Address for Correspondence: Dr. José Aderval Aragão, Associate Professor, Department of Morphology and the Postgraduate Applied Health Science Programs, Federal University of Sergipe (UFS), and Titular Professor of the Medical School, Tiradentes University (UNIT), Aracaju, Sergipe, Brazil, Res.: Rua Aloisio Campos 500, Bairro Atalaia, Aracaju, Sergipe, Brazil. CEP: 49035-020, Tel: +55-79-99191-6767 E-Mail: jaafelipe@infonet.com.br

\begin{tabular}{|c|c|c|}
\hline \multicolumn{3}{|c|}{ Access this Article online } \\
\hline \multirow{2}{*}{$\begin{array}{l}\text { Quick Response code } \\
\text { DOI: } 10.16965 / \text { ijar.2016.517 }\end{array}$} & \multicolumn{2}{|c|}{$\begin{array}{l}\text { Web site: International Journal of Anatomy and Research } \\
\qquad \text { ISSN 2321-4287 } \\
\text { www.ijmhr.org/ijar.htm }\end{array}$} \\
\hline & $\begin{array}{l}\text { Received: } 22 \text { Dec } 2016 \\
\text { Peer Review: } 23 \text { Dec } 2016 \\
\text { Revised: None }\end{array}$ & $\begin{array}{l}\text { Accepted: } 06 \text { Feb } 2017 \\
\text { Published (O): } 28 \text { Feb } 2017 \\
\text { Published (P): } 28 \text { Feb } 2017\end{array}$ \\
\hline
\end{tabular}

\section{INTRODUCTION}

The renal artery originates predominantly in the lateral surface of the abdominal descending aortic artery, below the superior mesenteric artery $[1,2]$, at the intervertebral disc level between the lumbar vertebrae $L 1$ and $L 2[1,3]$. In rare cases it can be originated below the celiac trunk or below the inferior mesenteric artery [2].

Among all its anatomical variations one of the most common is the presence of additional renal arteries [4,5]. This occurrence can become a complicating factor in renal surgeries, and particularly in kidney transplants [4]. A good 
understanding about anatomical variations of the renal arteries is important not only for anatomists, but mostly for urological surgeons on the formulation of better conduct on the renal transplants procedures $[4,6,7]$. The present study had the goal to report a case of renal artery bilateral duplicity in a male fetus.

\section{CASE REPORT}

During the routine dissection on the anatomy laboratory of the Federal University of Sergipe, São Cristóvão, SE, Brazil, was found, bilaterally, the presence of double renal arteries (Fig. 1), in a male human fetus with estimated age of 30 weeks (hallux-calcaneus measure). The arteries were originated on the lateral side of the abdominal descending aortic artery. The two renal arteries on the right side, one superior and other inferior, measured $6,68 \mathrm{~mm}$ and $5,85 \mathrm{~mm}$ respectively. Both bifurcated into two new arteries before entering the renal hilum. On the left side, the two arteries, superior and inferior, measured 4,16 $\mathrm{mm}$ and 9,93 $\mathrm{mm}$ respectively, and only the superior one bifurcated itself before entering the hilum.

Fig. 1: Bilateral double renal arteries.

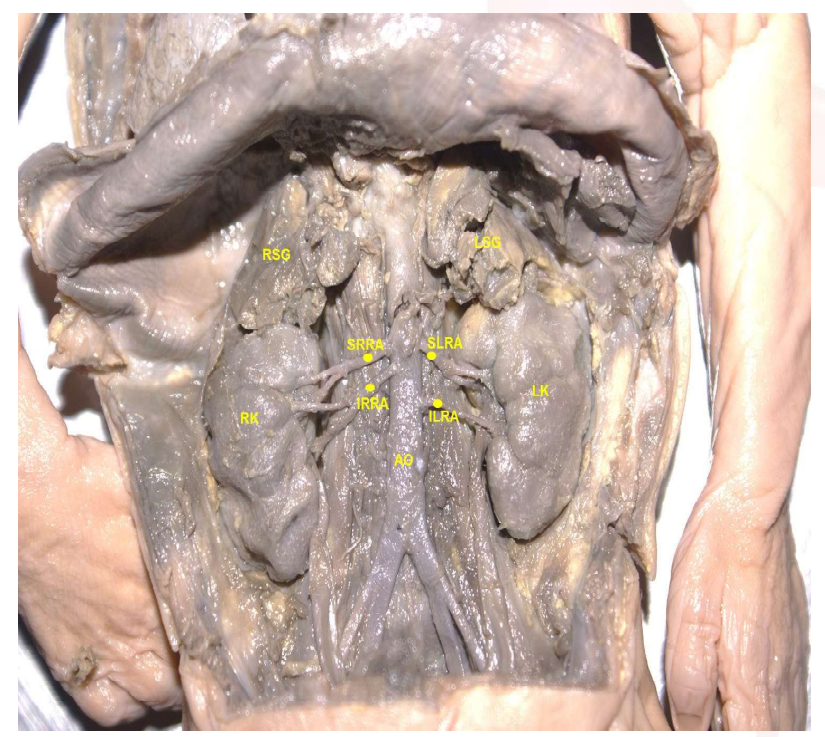

AO - Aorta, RK - Right kidney, LK - Left kidney,

RRA -Superior right renal artery, IRRA - Inferior right renal artery, SLRA - Superior left renal artery,

ILRA - Inferior left renal artery, RSG - Right suprarenal gland, LSG - Left suprarenal gland

\section{DISCUSSION}

The number of renal arteries can be considered as a variation most frequently found on the renal system. The knowledge about the number variation of renal arteries is extremely important for the vascular clinic and imageologists [3]. The accessory renal arteries range from $18.3 \%$ and $36.1 \%$ of the cases, on the right side the variation is from 11 to $16 \%$ and on the left side from 10 to $23 \%$, and in both sides it can get to $5 \%[1,4,5,8]$. In our study, two double bilateral renal arteries were found. While studying 356 kidneys from 178 cadavers Ogeng'o et al. [9] reported that $59.5 \%$ of the bilateral arteries penetrated parallelly in the renal hilum and only $7.1 \%$ penetrated crosswise. In our study, most renal arteries penetrated parallelly in the kidneys and were divided before penetrating the hilum. The presence of mutiple renal arteries and their mode of penetrating the renal hilum is of great surgical importance, specially, in the transplants' complex surgical procedure $[3,10-13]$. Thereby we consider that the present anatomical discovery can contribute to the enlargement of this kind of knowledge, especially regarding the occurrence of bilateral duplication of renal arteries.

\section{CONCLUSION}

The present finding is a contribution to the knowledge of possible anatomical variations of the renal arteries, which can help imageologists, and, specially, vascular and urological surgeons in endovascular procedures and kidney transplants.

\section{Conflicts of Interests: None}

\section{REFERENCES}

[1]. Aragão JA, de Oliveira Pacheco JM, Silva LA, Reis FP. Frequency of multiple renal arteries in human fetuses. Surg Radiol Anat. 2012 Mar;34(2):133-6.

[2]. Deshpande SH, Bannur BM, Patil BG. Bilateral multiple renal vessels: a case report. J Clin Diagn Res. 2014 Jan;8(1):144-5.

[3]. Natsis K, Paraskevas G, Panagouli E, Tsaraklis A, Lolis $E$, Piagkou $M$, Venieratos $D$. A morphometric study of multiple renal arteries in Greek population and a systematic review. Rom J Morphol Embryol. 2014;55(3 Suppl):1111-22.

[4]. Johnson PB, Cawich SO, Shah SD, Aiken W, McGregor RG, Brown H, Gardner MT. Accessory renal arteries in a Caribbean population: a computed tomography based study. Springerplus. 2013 Sep 8;2:443.

[5]. Aragão JA, Gomes HL, Costa HVD, Marcelo IS, Nunes PS. Double right renal vein: clinical and surgical implications and review of the literature. International Journal of Basic and Applied Sciences. 2015 Mar;4(2):178-82. 
[6]. Krishnaveni C, Kulkarni R. A right ectopic kidney with bilateral multiple anomalies of the renal vasculature - a case report. J Clin Diagn Res. 2013 Jan;7(1):150-3.

[7]. Ali Mohammed AM, Elseed Abdalrasol RG, Alamin Abdalhai K, Gommaa Hamad M. Accessory renal vessels. Acta Inform Med. 2012 Sep;20(3):196-7.

[8]. Ozkan U, Oðuzkurt L, Tercan F, Kizilkiliç O, Koç Z, Koca N. Renal artery origins and variations: angiographic evaluation of 855 consecutive patients. Diagn Interv Radiol. 2006 Dec;12(4):183-6.

[9]. Ogeng'o JA, Masaki CO, Sinkeet SR, Muthoka JM, Murunga AK. Variant anatomy of renal arteries in a Kenyan population. Ann Transplant. 2010 JanMar;15(1):40-5.

[10]. Aragão JA, Santana DPA, Brandão ECC, Andrade VFA, Freire MRM, Reis FP. Bilateral accessory renal arteries in a fetus: importance for surgical and radiological practice. International Journal of Basic and Applied Sciences. 2015 Jun;4(3):288-90.
[11]. Rusu MC. Human bilateral doubled renal and testicular arteries with a left testicular arterial arch around the left renal vein. Rom J Morphol Embryol. 2006;47(2):197-200.

[12]. Genc V, Karaca AS, Orozakunov E, Cakmak A, Sevim Y, Ustuner E, Oztuna D, Hazinedaroglu SM. Multiple renal arteries challenge in laparoscopic donor nephrectomy: how far can we go? J Korean Surg Soc. 2011 Apr;80(4):272-7.

[13]. Shashikala P, Anjali W, Anshuman N, Jayshree D. A case report: double renal arteries. Int J Anat Var. 2012 Jul;5:22-4.

How to cite this article:

José Aderval Aragão, Eder Santos Souza, Felipe Matheus Sant'Anna Aragão, lapunira Catarina Sant'Anna Aragão, Francisco Prado Reis. DOUBLE BILATERAL RENAL ARTERY IN HUMAN FETUS. Int J Anat Res 2017;5(1):3513-3515. DOI: 10.16965/ ijar.2016.517 